\title{
FARMERS' PERCEPTIONS OF THE RICE FARMING INSURANCE PROGRAM IN THE SUB-DISTRICT OF EAST BUAY MADANG, EAST OGAN KOMERING ULU REGENCY, SOUTH SUMATRA PROVINCE OF INDONESIA
}

\author{
Purwadi $^{\star}$, Minha Amruzi, Lifianthi \\ Faculty of Agriculture, University of Sriwijaya, Indonesia \\ ${ }^{\star}$ E-mail: purwadi701@gmail.com
}

\begin{abstract}
The agricultural sector has a fairly high risk of uncertainty, including the level of crop failure due to extreme climate change, attacks of pests and plant diseases, floods, droughts, and price uncertainty that is detrimental to farmers. To reduce the risk of crop failure faced by rice farmers, the government runs the Rice Farming Insurance (RFI) program. This study aims to analyze farmers' perceptions of implementations of the RFI program in East Buay Madang District, East Ogan Komering Ulu Regency, South Sumatra Province. The data collected through the questionnaire it was processed by tabulation and analyzed using the Likert Scale method. The indicators studied include the socialization of the RFI program, registration of insurance participants, RFI premiums, submission of insurance claims, insurance benefits, and the potential for sustainability of the RFI program. Three parameters of indicators that must answer by the sample farmers. The questionnaire was structured with answer choices Strongly Agree (SA), Agree (A), and Disagree (DA). The frequency of the answers of the sample farmers is presented in the form of percentages and the average score which is categorized into the criteria of high, medium, and low. As a result, the perception of farmers who are classified as high on the insurance participant registration indicator with an average score of 2.41, insurance benefits with an average score of 2.69 , and the potential for sustainability of the RFI program with an average score of 2.57 . The perception of farmers who are classified as moderate on the indicators of the socialization of the RFI program with an average score of 2.18, the RFI premium with an average score of 2.16 , and the insurance claim indicator with an average score of 2.11.
\end{abstract}

\section{KEY WORDS}

Rice, farming insurance, farmers perceptions, indicators.

The risk of uncertainty in the agricultural sector is quite high. These risks include the risk of crop failure due to extreme climate change, attacks of pests and plant diseases, flooding, drought, and price uncertainty that harms farmers. To reduce farmers' losses due to this risk, the government runs the Rice Farming Insurance (RFI) program. The pilot implementation of the RFI program in South Sumatra from 2012-2014, located in East Buay Madang District, East Ogan Komering Ulu Regency. After the trial period, the RFI program is continuing today. Farmers in OKU Timur District have received payments for this insurance claim several times. The government-subsidized premium is 80 percent from IDR 180,000 per hectare, which is IDR 144,000 per hectare per planting season. Farmers only pay a premium of IDR 36,000 per hectare per growing season. The rice fields of farmers participating in insurance, premium payments, and the realization of RFI claims in South Sumatra in 2018 decreased compared to 2017. The area of rice fields of RFI participants in 2017 was $31,056.81$ hectares with a total premium of IDR 5,590,225,800 and claim payments of $\mathrm{Rp} 25,481,746,543$. In 2018 , the area of rice fields participating in the RFI was $17,661.08$ hectares or decreased by $13,395.73$ hectares $(43.13 \%)$. Premiums also decreased by IDR $2,411,231,400$ or $43.13 \%$. Likewise, the money for insurance claims decreased by IDR $21,531,596,543$ (84.49\%).

The largest realization of farmers' claims in East Ogan Komering Ulu Regency occurred in 2017 due to crop failure due to planthopper attacks. The area of rice fields that participated in the RFI program was $13,882.69$ hectares, a decrease of $84.40 \%$ when 
compared to 2018. For premium payments in 2018, it decreased by IDR $2,498,884.2$ or $84.40 \%$, when compared to 2017 which only paid premiums. IDR 461,860,200. Likewise, insurance claim payments in 2018 also experienced a drastic decline, from IDR $7,904,725,000$ to IDR 406.5 million, or a decrease of $94.86 \%$. Farmer groups in East Ogan Komering Ulu Regency numbered 3,025 Groups spread over 20 sub-districts. The number of groups in detail consists of 1,272 beginner groups, 754 advanced groups, 87 intermediate groups, 10 main groups, and 899 unknown groups. The number of groups in East Buay Madang sub-district (research location) is 252 groups spread over 30 definitive villages. . Almost all of its members follow the RFI program. (Department of Agriculture East Ogan Komering Ulu, 2020).

Table 1 - Realization of RFI and Premiums, Claims of South Sumatra Province in 2017-2018

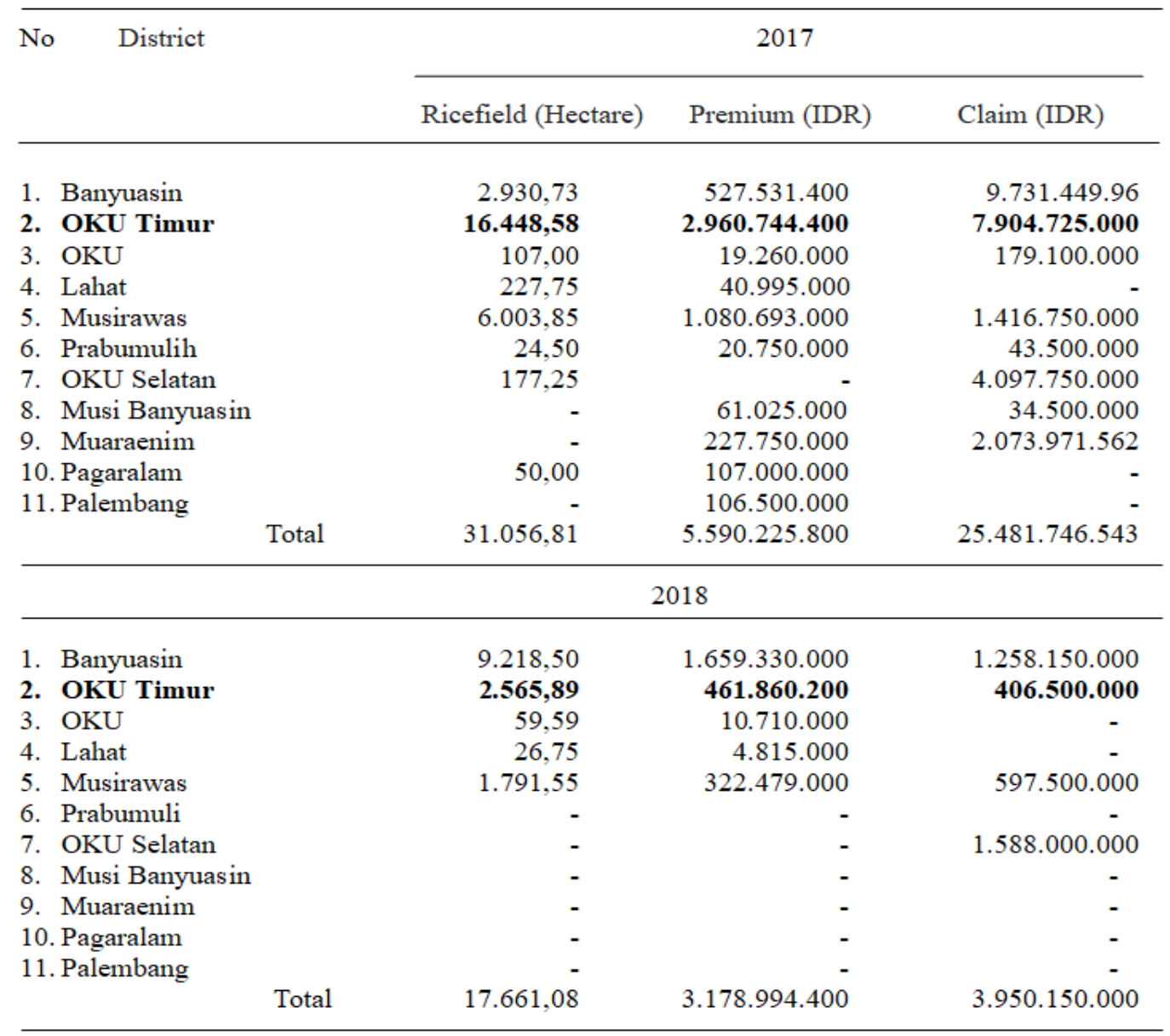

Source: South Sumatera Agriculture Service, 2019.

The decision of farmers to participate in this insurance program is influenced by many factors, including how the farmers themselves perceive the RFI program. Therefore, the authors are interested in raising the title of the research "Farmers' Perceptions of the Rice Farming Insurance Program in East Buay Madang District, East Ogan Komering Ulu Regency, South Sumatra Province."

There are six indicators in the RFI program that the authors examine. Indicators of socialization, participant registration, insurance premiums, claim submissions, insurance benefits, and the potential for sustainability of the RFI program. Each indicator consists of three statement parameters that must be answered by the sample farmers. This study hypothesis is that farmers' perceptions of the Rice Farming Insurance program are high. The purpose of this study was to analyze farmers' perceptions of the Rice Farming Insurance program in East Buay Madang District, East Ogan Komering Ulu Regency, South Sumatra Province. 


\section{METHODS OF RESEARCH}

This research was conducted in East Buay Madang District, East Ogan Komering Ulu District, South Sumatra Province. The data used are primary data from respondent farmers and secondary data from the Agriculture Service of East Ogan Komering Ulu Regency, South Sumatra Agriculture Service, Agricultural Extension Center, East Buay Madang District, and other relevant agencies. The primary data collection method was the survey method and direct interviews with respondent farmers using a questionnaire. The research was conducted from September 5 to October 25, 2020.

The method of determining the research area is done purposively (deliberately). Determination of the research area intentionally to get the desired sample and data. The research location is East Buay Mudang District, East Ogan Komering Ulu (OKU) District, which is the largest rice field in East OKU District participating in the RFI program. The locations taken are Sumber Mulyo Village, Berasan Mulya and Srikaton.

The sampling method (respondent farmers) is purposive sampling (deliberately) with a proportional system. Farmers who are members of farmer groups in the three research villages are identified first, whether they are participating or not participating in the RFI program. The total population in the three villages is 1,581 farmers. To determine the number of samples using the Slovin formula. (Sriati, 2012).

$$
n=\frac{N}{1+N e^{2}}
$$

Where: $\mathrm{n}$ - sample size; $\mathrm{N}$ - population size; e - critical value (limit of accuracy) desired (percentage of allowance for inaccuracy due to sampling error), where the critical value used is $10 \%$.

After being calculated based on the Slovin formula, the total sample size was 94,051 respondent farmers. The number of samples is round up to 100 respondent farmers. To determine the sample quota proportionally in the three research villages, the population of each Village was identified between farmers who participated in the RFI program and those who did not participate. Once known, it calculates using the formula:

$$
\text { Sampel Quota }=\frac{\text { Total Population Per Village }}{\text { Total Population of Three Villages }} \times \text { Total Respondents }(n)
$$

If the sample quota of respondents per Villages is known, the next step is to find the number of respondents who follow and do not take part in the RFI in Each Village, using the following formula:

$$
\begin{gathered}
\text { Respondents Participating in RFI }=\frac{\text { Farmers Participating in RFI }}{\text { Number of Farmers Population in Village }} \times \text { Sample Quota } \\
\text { Respondents Not Participating in RFI }=\frac{\text { Farmers Not Participating in RFI }}{\text { Number of Farmers Population in Village }} \times \text { Sample Quota }
\end{gathered}
$$

Results of calculation with this formula obtained 100 samples with details of 78 respondent farmers who participated in the RFI program and 22 respondent farmers who did not participate in the RFI program. That can be seen in the table below:

Table 2 - Sample of Respondent Farmers Participating and Not Participating in the RFI Program

\begin{tabular}{lccccccc}
\hline Village & $\begin{array}{c}\text { Population } \\
\text { (Farmer/N) }\end{array}$ & $\begin{array}{c}\text { Population } \\
\text { Participant }\end{array}$ & $\begin{array}{c}\text { Population } \\
\text { Unarticipant }\end{array}$ & (n) & $\begin{array}{c}\text { Participant } \\
(\%)\end{array}$ & $\begin{array}{c}\text { Unparticipant } \\
\text { (n) }\end{array}$ \\
\hline Sumber Mulyo & 765 & 643 & 122 & $\mathbf{4 0}$ & 3,23 & $\mathbf{8}$ & 2,35 \\
$\begin{array}{l}\text { Berasan Mulya } \\
\text { Srikaton }\end{array}$ & 329 & 166 & 163 & $\mathbf{1 1}$ & 0,89 & $\mathbf{1 0}$ & 2,93 \\
& 487 & 431 & 56 & $\mathbf{2 7}$ & 2,17 & $\mathbf{4}$ & 1,17 \\
\hline \multicolumn{1}{r}{ Total } & 1.581 & 1.240 & 341 & $\mathbf{7 8}$ & 6,29 & $\mathbf{2 2}$ & 6,45 \\
\hline
\end{tabular}


To answer the hypothesis and objectives regarding farmers' perceptions of the RFI program in East Buay Madang District, East Ogan Komering Ulu Regency, South Sumatra Province, the author uses the Likert Scale (LS) method. There are six indicators namely, RFI socialization, RFI participant registration process, RFI premium, RFI claims, RFI benefits, and RFI sustainability potential. The six indicators each have three statement parameters. Each statement was given a score of 3 for the High criteria, a score of 2 for the Medium criteria, and a score of 1 for the Low criteria. Respondents' answers are categorized in class intervals with the formula:

$$
\mathrm{VR}=\mathrm{NST}-\mathrm{NSR} I \mathrm{~L}=\mathrm{VR}: \mathrm{NCl}
$$

Where: VR - Value Range; HVS - Highest Value Score; LVS - Lowest Score Score; IL - Interval Length; $\mathrm{NCl}$ - Number of Class Intervals.

The calculation for creating a component's Class Interval is:

- $\quad H V S=(3$ indicators $\times 3$ questions $\times$ weight of questions $(3))=27$;

- $\operatorname{LVS}=(3$ indicators $\times 3$ questions $\times$ weight of questions $(1))=9$.

Calculation of the total class interval:

$$
V R=H V S-L V S I L=V R: N C I
$$

The calculation for creating class intervals per indicator is:

- $\quad H V S=(3$ questions $x$ weight of questions $(3)=9$;

- $\quad$ LVS $=(3$ questions $x$ weight of questions $(1)=3$.

The calculation for creating class intervals for each statement is:

- $\quad \mathrm{NST}=(1$ question $\times$ question weight $(3)=3$;

- $\mathrm{NSR}=(1$ question $\times$ question weight $(1)=1$. as follows:

Based on the results of the above processing, the class interval values in the table are

Table 3 - Class Interval per Statement

\begin{tabular}{lll}
\hline No & Number of Class Intervals (per quetions) & Criteria \\
\hline 1 & $1,00 \leq \mathrm{x} \leq 1,67$ & Low \\
2 & $1,67<\mathrm{x} \leq 2,34$ & Medium \\
3 & $2,34<\mathrm{x} \leq 3,00$ & High \\
\hline
\end{tabular}

Source: Data Processed, 2020.

Based on Table 3, if the average score is greater than or equal to 1 but less than 1.67, then it is a low criterion for farmers' perceptions of RFI. Then, if the average score is greater than 1.67 but less than or equal to 2.34, then it is included in the moderate criteria, and if the average value is greater than 2.34 but less than or equal to 3 , then it is classified as high criteria for farmers' perceptions of the RFI program.

\section{RESULTS AND DISCUSSION}

East Ogan Komering Ulu (OKU) Regency is a lowland area with an average altitude of approximately 45 meters above sea level (asl), located at positions $103^{\circ} 40^{\prime}-104^{\circ} 33^{\prime}$ East Longitude, and $3^{\circ} 45^{\prime}$ and $4^{\circ} 55^{\prime}$ South Latitude. The area of East OKU is in the form of a land area of $337,000 \mathrm{Ha}$ or $3,370 \mathrm{Km}^{2}$. this regency has the following territorial boundaries:

- Northside: Bordered by Ogan Komering llir (OKI) Regency, South Sumatra;

- Southside: Bordering with Ogan Komering Ulu Regency (OKU) South and Lampung Province;

- Westside: Bordered by Ogan Komering Ulu Regency;

- East: Borders with Ogan Komering Ilir (OKI) Regency. 
Based on Law Number 37 of 2003 concerning the Establishment of East Ogan Komering Ulu Regency, South Ogan Komering Ulu Regency, and Ogan Ilir Regency, South Sumatra Province, East OKU is a new autonomous region. East OKU Regency was previously part of Ogan Komering Ulu Regency. Since its establishment, East OKU Regency has experienced significant developments in the field of government. Four years after its formation, East OKU, which originally had 16 sub-districts, was expanded to 20 sub-districts in 2007, 337 villages, seven sub-districts, and 1,403 hamlets. (BPS OKU Timur, 2018).

East OKU Regency has a tropical climate and tends to be dry with daily temperatures varying between $220 \mathrm{C}-310 \mathrm{C}$. East Ogan Komering Ulu Regency is an area with high rainfall. The highest rainfall occurs between November to May, and the lowest is from July to September. Rainfall that occurs can be influenced by climatic conditions, geographical conditions, and the rotation of air currents. As a result, the amount of rainfall recorded at each observation station or BPP/BIP is not the same. As a result of the geographical location and the hilly topographical conditions of the area, based on the climate classification according to Schmidt and Ferguson, the East OKU Regency is classified as a type C climate with a humidity level of $60 \%-70 \%$.

The number of wet months is 3.6 and dry months are 3.2 with an average starting from October and ending in July. Rainfall varies between 2,554 mm - 3,329 mm/year. The driest month is July with about $280 \mathrm{~mm}$ of rainfall. The dry period is between May and August with rainfall between $113 \mathrm{~mm}-175 \mathrm{~mm}$. The wind blows between $15-20 \mathrm{~km} / \mathrm{hour}$. Residents of East OKU Regency are all people who live in the territorial area of East OKU Regency for 6 (six) months or more and or those who live less than 6 months but aim to settle down. The population of East Ogan Komering Ulu Regency based on the 2017 projection is 664,017 people, consisting of 338,731 male residents and 325,285 female residents. Compared to the projected population in 2016, the population of Ogan Komering Ulu Timur grew by 1.135 percent. Meanwhile, the sex ratio figure in 2017 for the male population to the female population is 104.13, which means that the male population is greater than the female population. This shows that out of every 100 female residents there are 104 male residents. The population density in Ogan Komering Ulu Timur Regency in 2017 reached 197.98 people/km².

East Ogan Komering Ulu Regency is one of the centers of rice production in South Sumatra Province and a national food barn. This is supported by the Perjaya Dam and an adequate irrigation system network. With this irrigation system and irrigation network, farmers in East OKU Regency can plant rice at least twice a year. The area of irrigated rice fields in East OKU Regency is 44,264 hectares while non-irrigated rice fields are 41,624 hectares. So the total area of rice fields in East OKU is 85,888 Ha.

The agricultural sector in East Ogan Komering Ulu Regency is one of the leading sectors. Agriculture in Ogan Komering Ulu Timur consists of several sub-sectors, namely food crops, horticulture, plantation, forestry, animal husbandry, fishery sub-sectors, and includes nursery services and seed centers. Food crops sub-sector, especially rice crops, out of a total area of 44,264 hectares of irrigated rice fields, the location of the largest irrigated rice fields is in Buay Madang Timur District of 6,971 hectares. Meanwhile, the largest nonirrigated rice field is in the District of Madang Suku I with an area of 5,787 ha. For the type of lowland rice, the largest area is in East Buay Madang District and the widest ricefield is in Jayapura District.

East OKU District has schools of all levels, from Kindergarten to College. The number of schools in East OKU Regency is 1,031, ranging from kindergarten to university. These schools are both under the auspices of the Ministry of Education and the Ministry of Religion. Then, the number of teachers reached 11,343 people, with the number reaching students 150,891 students. In detail, in the 2019/2020 school year, East OKU Regency has the following schools, teachers. Students; for schools from 1,031 school units, the details consist of Kindergarten (TK) totaling 191 schools (State 13 Schools, Private 178). Raudatul Athfal/RA has as many as 87 schools. Elementary school (SD) as many as 407 schools (State 382 and Private 25). Madrasah lbtidaiyah/Ml as many as 84 schools. There are 87 junior high/junior high schools (51 public and 36 private schools). There are 63 Madrasah 
Tsanawiyah/MTs. High school/high school as many as 37 schools (20 public and 17 private schools). There are 37 vocational high schools/vocational schools, all of which are stateowned. There are 38 Madrasah Aliyah/MA schools (1 state school and 37 private schools).

In the 2019/2020 academic year, the total student number reached 150,891 students from kindergarten to university. Kindergarten students are 8,254 students (575 public students and 7,679 private students). Raudatul Athfal/RA School has 4,199 students, Elementary School 66,772 students (state 63,552 students and private 3,220 students). Madrasah Ibtidaiyah/MI has students 11,088, SMP has 22,506 students (state 18,880 students and private 3,626 students), Madrasah Tsanawiyah/MTs has 10,526 students, SMA has 12,116 students (state 9,721 students and private 2,316 students), SMK has 10,515 students and Madrasah Aliyah/MA the number of students is 4,915 students (965 state students and 3,950 private students).

The number of teaching staff for the 2019/2020 school year has reached 11,343 teachers, with details of kindergarten teachers totaling 839 teachers (state 79 teachers and private 760 teachers). Then, Raudatul Athfal/RA there are 373 teachers, SD there are 4,394 teachers (4,151 state teachers and 243 private teachers), Madrasah Ibtidaiyah/MI have 828 teachers, SMP has 1,686 teachers (1,368 state teachers and 318 private teachers). Then, Madrasah Tsanawiyah/MTs have 1,086 teachers, SMA has teachers 850 (654 state teachers and 196 private teachers), SMK has 676 teachers, and Madrasah Aliyah/MA has 611 teachers (65 state teachers and 546 private teachers). The existing health facilities in East OKU Regency until 2019 are four (4) Hospital units, 16 Polyclinic units. Then, 21 units of Community Health Service Centers (Puskesmas), 56 units of Supporting Health Centers. There are as many as 20 pharmacies for drug services or pharmacies. (BPS Kabupaten OKU Timur, 2020)

East Buay Madang District (BMT) has an area of $156.25 \mathrm{~km}^{2}$ or 20.500 hectares. There are 33 villages (30 definitive villages and 3 preparatory villages). The northern border is with the District of Buay Pemuka Bangsa Raja and the District of Belitang Madang Raya. In the south with Lampung Province, in the east with Belitang District, in the west with Buay Madang District.

The capital of East Buay Madang District is Karang Tengah. In general, the topography of Buay Madang Timur is a highland area. Most of the villages are located at an altitude of fewer than $\mathbf{5 0 0}$ meters above sea level (asl). Classification of areas based on this plain, if the area is located at an altitude of fewer than $\mathbf{3 0 0}$ meters above sea level, then this area is in the lowlands. If an area is at an altitude above 300 meters above sea level, it means that the area is in a highland. (BPS OKU Timur, 2020).

Buay Madang Timur has a tropical climate with quite high rainfall throughout the year. Rainfall in Buay Madang Timur ranges from $1000 \mathrm{~mm}-2000 \mathrm{~mm}$ per year with fairly even variations each month. Meanwhile, the air temperature ranges from $25^{\circ} \mathrm{C}$ to $33^{\circ} \mathrm{C}$. Buay Madang Timur sub-district has 33 villages, with details of 30 definitive villages and three preparatory villages. Geographically, all villages are located at an altitude of fewer than 500 meters above sea level (asl) and are not in coastal areas. Buay Madang Timur District is mostly an agricultural area, especially rice fields. The area of rice fields in Buay Madang Timur is almost 7,000 hectares.

In addition to rice fields (rice), there are also plantation crops in the form of rubber, coffee and cocoa. Then, some vegetables, horticulture, and fruit crops. The main source of income for the population is farming (rice). In a year can be harvested three times. Cropping patterns vary, sometimes Paddy-Rice-Palawija. Most of the three planting seasons all planted rice. Another job is trading. There are also construction workers, farm laborers, civil servants, and private employees.

Most of the land in Buay Madang Timur is used for rice farming. Of the existing rice fields, as many as 7,538.5 hectares of rice fields in this sub-district already use technical irrigation (BPS OKU Timur, 2020). The largest rice field is in Tanjung Sari Village, which is $549 \mathrm{Ha}$, while the smallest is in Berasan Mulya Village at $114 \mathrm{Ha}$.

This research was conducted in Sumber Mulyo Village, Berasan Mulya and Srikaton, East Buay Madang District, East Ogan Komering Ulu (OKU) Regency. This study took 100 
farmer respondents from the three villages. Respondent farmers in each village were taken based on the number of farmers who participated in the Rice Farming Insurance (RFI) program and those who did not participate in the RFI. With the proportional formula, the results obtained are 78 respondent farmers who participate in RFI and 22 respondent farmers who do not participate in the RFI program. Of the 78 respondent farmers who participated in the RFI, there were 40 respondent farmers in Sumber Mulyo Village, 11 respondents in Berasan Mulya, and 27 respondents in Srikaton Village. Then, of the 22 respondent farmers who did not participate in the RFI program, in Sumber Mulyo Village there were 8 respondent farmers, in Berasan Mulya 10 respondent farmers, and Srikaton Village there were 4 respondent farmers.

Age is the age of the respondent farmer at the time of the research, expressed in years. Age is related to the experience and maturity of farmers in doing farming. Age will also affect physical ability and response to new things in doing farming. There is a tendency that young farmers to adopt innovation more quickly because young farmers have the enthusiasm to know and find out what they don't know. The older the age of the farmer, the lower the physical ability of the farmer in doing farming.

Age is one of the factors related to the ability to work in carrying out activities, both farming and non-farming activities. Older farmers usually tend to be very conservative or less responsive to changes in technological innovation. (Soekartawi, 1999 in Novia Ambar Sari, 2020). Younger farmers have high enthusiasm to learn new things and tend to be responsive to change (Kartasapoetra, 1994 in Novia Ambar Sari, 2020).

Of the 78 respondent farmers (sample) who participated in the Rice Farming Insurance (RFI) program, dominated by farmers aged 31 to 40 years, namely 24 were respondent farmers $(30.77 \%)$. This age is in the second group. That is a very productive and group approaching maturity in thinking, acting/ and being responsive to technological changes. In the first group aged between 21-30 years, there were six respondents (7.70\%). Then, the third group aged between $41-50$ years reached $28.20 \%$ or 22 farmer respondents. That classified as productive and at the peak of emotional maturity in thinking and acting. The fourth group, aged 51-60 years, consisted of 16 respondent farmers or $20.51 \%$ of the farmers respondent who participated in the RFI program. In the fifth group aged between 61 70 years, there are $8.97 \%$ or seven respondent farmers, and in the sixth group aged between 71 - 80 years, there are three people or $3.85 \%$.

In the 22 farmers who did not participate in the RFI program, there were four age groups. The four groups are the second, third, fourth, and fifth age groups. While/, the first and sixth age groups do not exist. In the second age group between 31-40 years, there are $31.82 \%$ or seven farmer respondents. The third, $41-50$ years old groups, consisted of $45.45 \%$ or ten farmer respondents, the fourth group between $51-60$ years old had three farmers or $13.64 \%$, and the fifth group between $61-70$ years old had $9.09 \%$ or two farmers.

Education is a process that a person goes through to improve knowledge, skills, and attitudes. To process the increasing knowledge, attitudes, and skills, pursue through formal and non-formal educations. A person's educations will affect his mindset in dealing with a problem. A person's level of educations will affect his personal quality. A low education will result in getting less personality knowledge and utilization of the resources available around us. Conversely, a higher level of educations made a person able to accept the information and innovations conveyed.

The education level of the respondent farmers, both those who participated in the RFI program and those who did not, was dominated by junior and senior high schools. Of the 78 respondents who participated in the RFI program, there are 32 respondents from high school or $41.03 \%$, there were 24 respondents who graduated from junior high school or $30.77 \%$, there were 19 respondents who graduated from elementary school or $24.36 \%$. The rest graduated from D3, S1, and S2, with one respondent farmer each. For the education level of 22 respondents who did not follow the RFI program, namely elementary school graduates, there were five respondents or $22.73 \%$. There are 9 junior high school graduates or $40.92 \%$, six respondents from high school graduates or $27.27 \%$, and D3 and S1 graduates each having one respondent or $4.54 \%$. 
The area of land cultivated by respondent farmers will affect the amount of agricultural production. The wider the area of agricultural land owned, the higher the products produced. High production indirectly affects income. The rice field also determines the amount of income obtained from farming. The rice field owned by 78 respondent farmers who participated in the RFI program in Sumber Mulyo, Berasan Mulya, and Srikaton villages was quite varied. Most of the rice field is between $0.25 \mathrm{Ha}$ to $0.75 \mathrm{Ha}$. The respondent farmers have rice fields less than $0.25 \mathrm{Ha}$ there are 23 people or $29.49 \%$, respondents with rice fields between $0.25 \mathrm{Ha}$ to $0.50 \mathrm{Ha}$ there are 25 people or $32.05 \%$. And then, respondent farmers who own rice fields between $0.51 \mathrm{Ha}$ to $0.75 \mathrm{Ha}$ as many as 26 people or $33.33 \%$. Finally, the respondent farmers with have rice fields of more than $0.91 \mathrm{Ha}$ are four respondents or $5.13 \%$.

Furthermore, for the 22 respondent farmers who did not participate in the RFI program, most of the rice field owned was less than $1 \mathrm{Ha}$. The details are as follows, farmers who own land less than $0.25 \mathrm{Ha}$ as many as 5 people or $22.73 \%$, respondent farmers who own land between $0.25 \mathrm{Ha}$ to $0.50 \mathrm{Ha}$ as many as 8 people or $36.36 \%$. Then, farmers with land between $0.51 \mathrm{Ha}$ to $0.75 \mathrm{Ha}$ were 9 people or $40.91 \%$.

Farming experience affects farmers in running their farming. The longer a person's experience in farming, the more maximal the results will be. Farmers who have been farming for a long time have a high level of knowledge, experience, and skills in running a Paddy farming. Farming experience is divided into three categories, namely less experienced $(<5$ years), medium experienced (5-10 years), and experienced ( $>10$ years). Farmers have different farming experiences or lengths of farming (Soeharjo and Patong, 1999).

Most of the respondent farmers in Sumber Mulyo, Berasan Mulya and Srikaton villages are very experienced. A total of $39.74 \%$ or 31 farmers have more than 20 years of farming experience. Then, there are 20 farmers with sufficient experience (5-10 years) or $25.64 \%$. There are 24 farmers whose farming experience is between 11 to 20 years or $30.77 \%$.

Income is the income obtained by farmers from rice farming minus the expenditure of farming costs. Income can affect the decision-making process in implementing rice farming. Income can also influence farmers' decisions to join the Rice Farming Insurance (RFI) program or not. The higher the income obtained by farmers in agricultural activities will affect the availability of greater capital. This is the cause of the opportunity for farmers to apply new innovations/technology.

The income of 78 respondent farmers who participate in the RFI program is mostly between IDR $2,100,000$ to Rp. $3,000,000$, which is $41.03 \%$ or 32 people. Then, 21 respondent farmers or $26.92 \%$ have income between IDR 500,000 - IDR 1,000,000. Then, 18 respondent farmers have incomes between IDR 1,100,000 - IDR 2,000,000. The rest, 7 respondent farmers or $8.97 \%$ have income greater than IDR 3,000,000.

The author examines farmers' perceptions of the Rice Farming Insurance Program (RFI) using six indicators with three parameters for each indicator. The six indicators are the socialization of the RFI program, registration of RFI participants, insurance premiums, insurance claims, the benefits of the RFI program, and the potential for the sustainability of the RFI program. For information, the RFI program began to be implemented in East OKU Regency during the planting season of October 2012 - March 2013. The government carried out socialization in the early stages of the trial and the south Sumatera, the trial was carried out on technical irrigation land in East Buay Madang District. So that the East OKU community is no stranger to the RFI program. The socialization stage involves various parties such as the Department of Agriculture and other relevant agencies as well as the spearheads of agricultural extension workers. The target object of socialization is of course farmers who are members of farmer groups.

1. Socialization of the Rice Farming Insurance Program. Farmers' perceptions of the socialization of the RFI program have an average score of moderate criteria. The frequency of farmers' answers is $72.67 \%$ strongly agree, $26 \%$ agree, and $1.33 \%$ disagree. Then the average score of each respondent farmer's answer is 2.18. This score is categorized as moderate because the class interval value is more than 1.67 but less than 2.34. Farmers assessed that the frequency of socialization was still lacking namely, $42 \%$ of farmers stated 
that they strongly agreed that the frequency of socialization of the RFI program was as expected. The rest, $56 \%$ of farmers agree, and $2 \%$ disagree with a score of 1.26 (Low). So far, according to farmers, RFI socialization is only carried out at the beginning of the RFI program implementation. In the future, farmers hope that officers, especially insurance service providers, go directly to the field so that they know the condition of farmers in the field. Parameter statements regarding farmer participation during the socialization implementation, $89 \%$ strongly agree, $10 \%$ agree and $1 \%$ disagree with a score of 2.67 (high). Statements regarding socialization can increase farmers' knowledge, $87 \%$ answered strongly agree, $12 \%$ agreed and $1 \%$ disagreed with a score of 2.61 (High).

2. Participant of RFI Registration. Registration of insurance participants, since 2019 online with the SIAP (Agricultural Insurance Information System) application. Previously, registration was done manually, filling out forms coordinated by farmer groups under the guidance of PPL. Then in stages, it is submitted to the BPP (Agricultural Extension Center) unit in the sub-district to the Regency/City Agriculture Service. Then, submitted it to the insurance company. With the change in the registration system from manual to digital/online, farmers find it very helpful especially when there is a special administrative staff (admin) who handles this application. Forms and completeness are collected through PPL and uploaded by the appointed admin. Farmers' perceptions of the RFI registration process are high. On average $80.34 \%$ of farmers stated strongly agree, $18.33 \%$ agree and the remaining $1.33 \%$ disagree, with a score of 2.41 and including high criteria. When viewed per statement parameter, there are two parameters that have high scores with high criteria. The two parameters are that farmers can register for RFI easily and farmers can meet the requirements, each with a score of 2.64 and 2.61. Parameter statements regarding easy registration procedures and good service, the score includes the moderate criteria, namely 1.98. Farmers are helped because there is a special officer as the SIAP application admin. The registration is also facilitated by the farmer groups through the head and the head of the farmer group in contact with the admin staff.

3. RFI Program Premiums. In the indicator of insurance premiums, farmers' perceptions are classified as medium criteria. On average, $67.33 \%$ of farmers strongly agree, $19 \%$ agree and $13.67 \%$ disagree. The average score is 2.16 and includes medium criteria because the score is more than 1.00 but less than 2.34. Farmers' perceptions of the premium subsidy parameters are IDR $144,000 / \mathrm{Ha} /$ planting season and the ability to pay premiums of Rp. 36,000/Ha/Planting Season, which are categorized as high criteria. As many as $87 \%$ of farmers stated that they strongly agree that they pay a premium of IDR $36,000 / \mathrm{Ha} / \mathrm{Planting}$ Season, $12 \%$ agree, and $1 \%$ disagree with a score of 2.61 (High). Likewise, with the government subsidy of IDR $144,000 / \mathrm{Ha} /$ Planting season as many as $86 \%$ of farmers stated strongly agree, $12 \%$ agree, and $2 \%$ disagree with a score of 2.58 (High). Meanwhile, if the subsidy is revoked, or farmers pay the premium independently of IDR $180,000 / \mathrm{Ha} / \mathrm{Planting}$ Season, only $29 \%$ strongly agree, $33 \%$ agree, and the remaining $38 \%$ disagree. The score is 1.30 , so it includes the criteria for low farmers' perceptions of this statement. Farmers object if the government removes the $80 \%$ premium subsidy (IDR 144,000). Farmers do not want to pay the premium independently of IDR $180,000 / \mathrm{Ha} /$ Planting Season because if there is no insurance claim their money will be forfeited.

4. RFI Program Claim. Farmers' perceptions of the claims indicators for the RFI program are, on average, classified as medium criteria with a score of 2.11 , where $70.33 \%$ of farmers state strongly agree, $13 \%$ agree, and $16.67 \%$ disagree. Judging from the statement parameters, two parameters are classified as high criteria. The parameters of the claim requirements are easy to fulfill and appropriate as much as $83 \%$ stated strongly agree, $14 \%$ agree, and the remaining $3 \%$ disagree with a score of 2.49 including high criteria. The second parameter, procedure, and mechanism for submitting claims are easy, as many as $84 \%$ stated strongly agree, $14 \%$ agreed, and the remaining $2 \%$ disagreed with a score of 2.52 including high criteria. While the statement parameters regarding the payment of claims were in line with expectations, as many as $44 \%$ stated strongly agree, $11 \%$ of farmers agreed, and the remaining $45 \%$ of farmers said they did not agree. The score is 1.32 and includes low criteria. According to farmers, the realization of claim payments often does not 
match their submissions. Then, the disbursement of the claim money takes a long time, approximately one month after the submission, while when there is a crop failure they need funds to replant their rice fields.

Table 4 - Farmers' Perceptions of the RFI Program in East Buay Madang

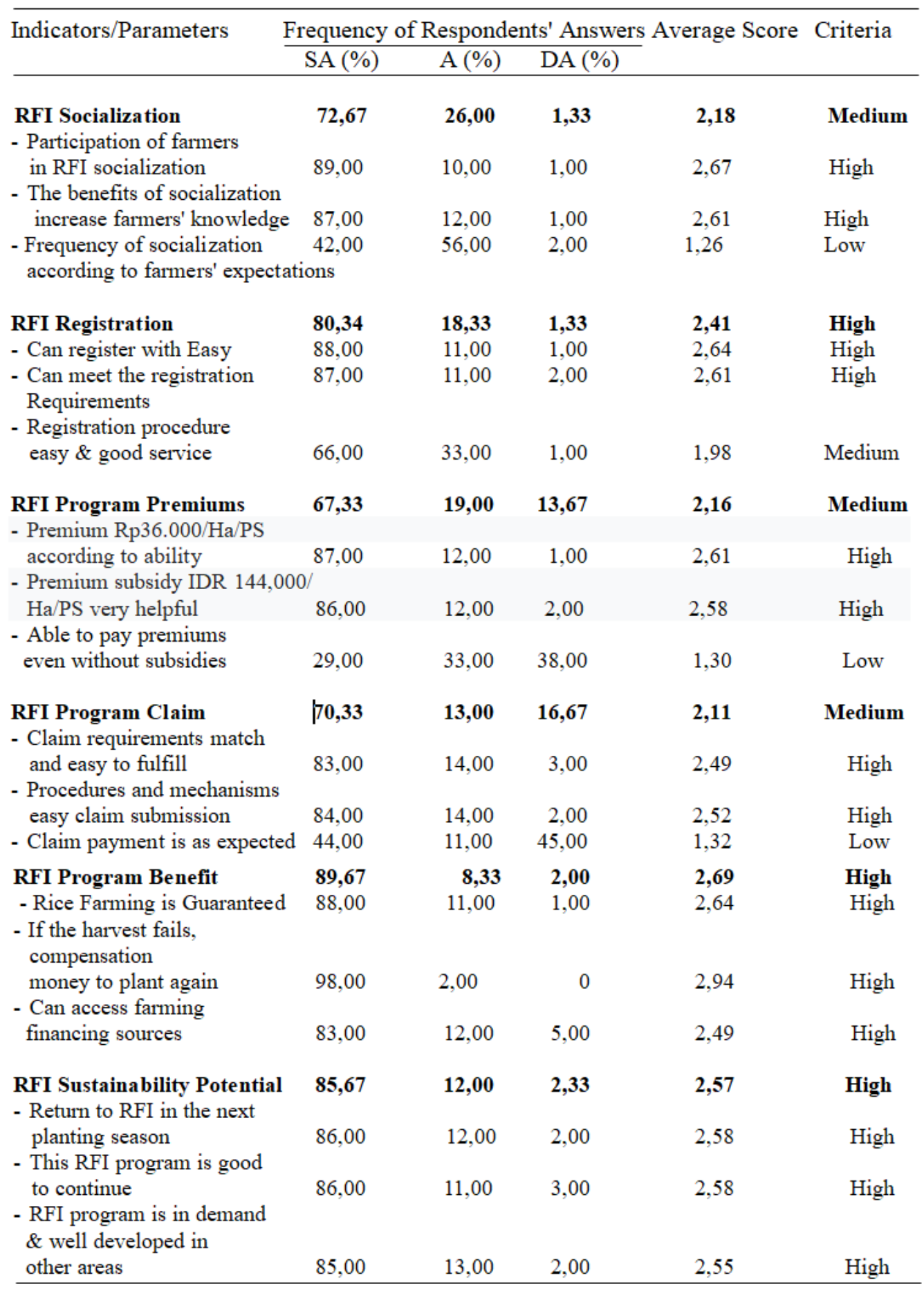

Source: Processed from Primary Data.

5. Benefits of the RFI Program. Furthermore, farmers' perceptions of the benefits of the RFI program on average include a high criterion score of 2.69 . As many as $89.67 \%$ of farmers stated strongly agree, $8.33 \%$ agreed, and $2 \%$ of farmers said they did not agree. If you look at the statement parameters, all of them are classified as high score criteria. Paddy farming parameters are guaranteed as many as $88 \%$ of farmers stated strongly agree, $11 \%$ 
agreed, and $1 \%$ disagreed with a score of 2.64 , including high criteria. The second parameter, if the harvest fails, the compensation can be replanted, as many as $98 \%$ of farmers stated strongly agree and $2 \%$ agreed with a score of 2.94 including high criteria. The third parameter of farmers can access sources of farm financing, as many as $83 \%$ of farmers stated strongly agree, $12 \%$ agree, and 5\% disagree with a score of 2.49 including high criteria.

6. RFI Program Sustainability Potential. Lastly farmers' perceptions of the potential for sustainability of the RFI program. On average, $85.67 \%$ of farmers stated strongly agree, $12 \%$ agreed and $2.33 \%$ of farmers disagreed with a score of 2.57 including high criteria. The three parameters indicate a score that is classified as a high criterion. As many as $86 \%$ of farmers stated strongly agree and stated that they would participate in the RFI program in the next planting season, $12 \%$ agreed and $2 \%$ disagreed with a score of 2.58 . Then, $86 \%$ of farmers stated that they strongly agree if the RFI program continues, $11 \%$ of farmers agree and $3 \%$ disagree with a score of 2.58 . The last parameter, as many as $85 \%$ of farmers stated that they strongly agreed if the RFI program was developed in other areas and had many enthusiasts, $13 \%$ agreed and $2 \%$ disagreed with a score of 2.55 . If the six scores of each indicator are combined and divided by six, the average score is 2.35 . This value is a high criterion because the number is greater than 2.34 but smaller than 3.00 . Thus, farmers' perceptions of the RFI program in East Buay Madang District are high criteria.

\section{CONCLUSION}

Farmers' perceptions of the registration indicators, the benefits of the RFI program, and the potential for the sustainability of the Rice Farming Insurance (RFI) program are high. Meanwhile, farmers' perceptions of the indicators for the socialization of the RFI program, premiums, and insurance claims are in the medium category.

Based on the results of interviews in the field and the results of the discussion the authors suggest the following:

1. Agricultural extension officers and agricultural insurance service providers should work together to increase the frequency of socialization related to the latest regulations regarding the $\mathrm{RFI}$ program;

2. The Government of the Republic of Indonesia through the Ministry of Agriculture

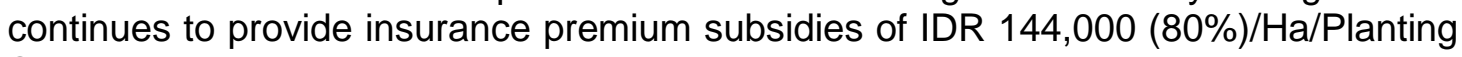
Season;

3. Insurance service providers appointed by the government to evaluate the timing of the disbursement of compensation funds (claims) for farmers.

\section{REFERENCES}

1. Arikunto Suharsimi. 2006. Research Methodology. Character Building. Yogyakarta.

2. Dian Andrayani. 2013. Agricultural Insurance as a Means to Improve Farmers' Welfare (Simulation Analysis at PT. Saung Mirwan and Mitra Taninya in Megamendung District, Bogor Regency). Bogor Agricultural University.

3. Central Bureau of Statistics. 2020. Ogan Komering Ulu Timur Regency in Figures.

4. Central Bureau of Statistics. 2019. South Sumatra in Figures.

5. Central Bureau of Statistics. 2018. South Sumatra in Figures. www.bpssumsel.go.id.

6. Mega Mustika, Anna Fariyanti, Neti Tinaprillah. 2019. Analysis of Farmers' Attitudes and Satisfaction Against Rice Farming Insurance Attributes in Karawang Regency, West Java. Agribusiness Forum (Vol 9 No 2: 200-214, September 2019).

7. Novia Ambar Sari, 2019. Time Allocation of Working and Non-Working Women is Relates to the Decision Making Process in Oil Palm Farmers' Households in Banyuasin Regency. Thesis of the Faculty of Agriculture, Sriwijaya University.

8. Resti Aprelesia, Rahmat Syahni, Lora Triana. 2019. Analysis of Factors Affecting Farmers' Decisions to Become Participants of Rice Farming Insurance in Pauh District, Padang City. Journal of Socio Economic on Tropical Agriculture, (Volume 1 No 3: 67-74).

9. Sriati, MS. 2012. Social Research Methods. Sriwijaya University Palembang. 